\title{
Does Job Satisfaction and Employee Commitment pave way for Employee Engagement in IT Sector
}

\author{
Rajeesh Viswanathan, N. Sarath Lal, Veena Prasad, Jahira Parveen
}

\begin{abstract}
:
Purpose: Present study is a descriptive and analytical in nature aiming to bring out the relationship of job satisfaction and employee commitment on employee engagement of the employees working in IT companies of South India.

Design/Methodology/Approach: This study adopts descriptive and analytical approach it, starts with clear variables which are derived from theory and based on these variables. The data for the study was collected through the structured questionnaire. The sample for the present study was collected from the IT companies working in South India. A total 785 questionnaires were returned by the respondents, this indicating a response rate of $59 \%$. The questionnaire uses five point Likert type response format is used for all the measures ranging from strongly agree to strongly disagree. SPSS 21 and Microsoft excel are the statistical packages and correlation and regression are the tools used in the present study
\end{abstract}

Findings: A significant relationship was found between job satisfaction and commitment with employee engagement of the employees working in IT companies of South India. If Job Satisfaction does not exist in an employee, his level of engagement would be minimal. Employee may be working to maintain hygiene factors according to Herzberg but the management won't be able to motivate him to either enhance productivity or engage him with the organization. Commitment comes when the hygiene factors are maintained. Every employees looks forward to ensure that the employee is committed. Only then they can motivate them to be engaged. Hence, it observed that all the commitment of employees are mandatory for employee engagement

Originality/value: This study provides insightful findings in understanding the role organizational competencies like job satisfaction and employee commitment play in facilitating employee engagement. This study also shows the importance of the demographic variables with employee's engagement. In spite of the limitations of the research, the study contributed to the international human resources management by exploring the South Indian IT company's context. The theoretical framework proposes the relationship between employee engagement, job satisfaction and employee commitment. The study has found that job satisfaction and employee commitment is correlated with employee engagement and serves as the important indicator for engaging employees.

Index Terms: Employee Engagement, Job Satisfaction and Employee Commitment

Revised Manuscript Received on July 05, 2019

Dr. Rajeesh Viswanathan, Asst Prof Dept of International Business, School of Management, Pondicherry University, Pondicherry.

N. Sarath Lal, Dept of International Business, School of Management, Pondicherry University, Pondicherry.

Dr Veena Prasad, Prof, Shir Ram college of Commerce, Mumbai

Dr. Jahira Parveen, Faculty of Management, SRM Institute of Technology, Chennai.

\section{INTRODUCTION}

Organizations have been expanding in an exponential manner. In this scenario all the organizations focuses on one thing that is increase the market share in order to be the market leader. One of the biggest nightmare being faced by the managers in organization is retaining of the talented employees and engaging them. For increasing the organizations effectiveness and enhancing productivity we need to have engaged employees. Hence, no organization can develop by ignoring employee engagement. Employee engagement is a widely used term in the current business scenario and there are very less studies have been done in academics when compared to practioners and consulting firms Robinson et al (2004). In the past few years, the companies are showing interest in employee engagement and many claim employee engagement contributes to success of the organization and increase performance Bates, 2004. Information technology (IT) is one of the main industries in India which is growing vastly in the last decades. Quarter and more of India's service exports is by information technology services and India acts as one of the global service sourcing in IT and they are expected to grow in the coming years. Globally Indian it sector is growing at a rate of $4.6 \%$ in 2013 India IT software service acts as a main contribution in the field of exports and is a key element in providing export services. There is a 55\% of total growth in IT-BPM industry which is accounting over USD 1.25 trillion. In hardware it was I USD trillion, which accounted for $45 \%$ of growth.

Many definitions have been given to engagement as "the harnessing of organization members' selvesto their work roles; in engagement, people employ and express themselves physically, cognitively, and emotionally during role performances" Kahn (1990). "Engagement is not an attitude; it is the degree to which an individual is attentive and absorbed in the performance of their roles and while OCB involves voluntary and informal behavior that can help co workers and the organization, the focus of engagement is one's formal role performance rather than extra - role and voluntary behaviour" Saks, A.M (2006). Then, Schaufeli et al (2002) defines engagement "as a positive, fulfilling, work-related state of mind that is characterized by vigor, dedication and absorption".

Creating a culture of engagement is a very intuitive, teacher drove experience where leaders figure out how to expand employee engagement and reinforce teams, which

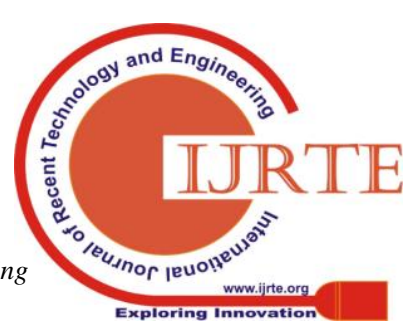


prompts a substantial results in business. It is a manual, process - situated, activity learning session. It concentrates on what the organization needs to do, and in addition what individual employees need to do to make collegial groups and culture of engagement. The general work experience is disintegrating especially with respect to enablement, self-governance and feeling of achievement. The normal float is that the work experience is decaying more than it is moving forward. Specifically, view of assets and projects that capacitate are falling cross wise over numerous business sector. Employees who are locked in however not capacitated are at danger of hatred, burnout, disengagement, immaterial profitability and turnover.

As there are so many definitions and advantages given for employee engagement it is seen that there is disengagement is being developed among the employees Richman (2006) and so this study intends to check employee engagement with job satisfaction and employee commitment and the contribution of the variables to employee engagement. This study focuses on employee engagement in selected five IT companies from India.

\section{Research Gap}

Employee engagement is always an advantage for the organization in today's business environment which is competitively enough. But in India, the importance of employee engagement is different due to variety of reasons like diverse environment in each organization, how committed and satisfied they are in the work they do and with the organization. Considering these, the present study intends to concentrate on the satisfaction level and commitment level of the employee in the organization.

\section{Need of the present study}

In the current global scenario organizations have been expanding in an exponential manner. NASSCOM annual report of 2012 states that the attrition rate is $27 \%$ in IT sector. In this process top management have been focussing more on strategies \& targets to expand and enhance their market share with minimal focus on the HR area. On the other hand HR has been into routine HR functions ignoring the factors like enhancing talent management and employee engagement. With this scenario, employees started moving from organizations for minimal gains since they were lacking engagement. Hence, it is felt that there is a need for the organisation to enhance employee engagement methods, in order to sustain steady growth and development.

\section{Scope of the Study}

The study intends to find employee engagement in the IT sector. India is one of the largest hub of IT industry and employee engagement is being measured from these companies. The respondents of this study are the employees from select five IT companies from south India.

\section{Statement of the problem}

To accomplish the organizational goals these IT companies rely on knowledge workers. Engaging a knowledge worker is a challenging task. For business performance to be achieved attracting and engaging the talent is needed for the organization and will be challenging enough. The ultimate objective of the organization to make employee engagement happen in the organization. Employee maximizing their value to the organization to increase engagement. But the definition of what it takes to make engagement happen is not based solely on competitive rewards; it is determined by the employee and is a moving target. The real challenge is faced not in hiring but in engaging them. Employee commitment, Job Satisfaction play a vital role in engaging employees.

\section{Research Question}

The central research question of this study is to analyse how the employee commitment and job satisfaction influence employee engagement?

- What is the influence of employee commitment on employee engagement?

- What is the influence of job satisfaction on employee engagement?

\section{Review of literature}

\section{Employee Commitment}

Oyesoji Aremu and C. Adeola Adeyoju examine that the 'Effect of mentoring on commitment to exert effort, job satisfaction and sex into the Nigeria police'. Certainly one of their goals that are major find out that will here be is any difference between feminine and police that is male on job. The study demonstrates Mentoring having an impact that is fantastic commitment to work and male and feminine authorities that is nigerian. Therefore the study that is scholarly finds that male have more specialized in the job than feminine in Nigerian police. Plus in 2008 Ike-ElechiOgba, examines that whether age and earnings having any impact on worker commitment in Nigerian banking sector. The reason that is main this research should be to examine there is any connection that is significant income and age with Employee Commitment. Those age between 31-35 are less committed from this research it's unveil that high income team are less committed to work while compare to low profits group, Likewise the income team that is high. Moreover understood through the factors that younger workers tend to be devoted to exert effort rather than aged people. Dr. Varsha Dixit and Ms. Monika Bhati was conduct a research that is extensive 'The effect of this worker commitment on suffered effectiveness in Auto-component industry in India'. The goal that is major of study have been identify the consequence of dedication (normative, affective and continuance) on sustained productivity. Principal and information that is secondary for conduct the study, and commitment that is affective normative dedication and constant dedication are taken as split variable and gratification as additional adjustable. The research demonstrates that employee's commitment is a direct impact on sustained productivity. And all three commitments such as for example normative dedication, affective commitment and constant dedication are correlated with sustained productivity on car component industry in Asia.

Through the scholarly study it had been identified that absenteeism is adversely correlated with worker commitment to work also to the organization also. Such as for instance reduced dedication causes more range that is impressive of. Employee commitment measures are pertaining to relationship and mind-set to improve tendency to keep utilizing the organization and are based upon senior management, individual goals, 
past success and expectation of attaining occupation goals. Using this research it was unveil that employee additionally dedication and work satisfaction is strongly correlated. DovElizur, (1996) also learn within the ongoing work that is topic and commitment. The target that is major of research was indeed examining the partnership between different work values and dedication. Right here 24 work value identified by the Elizur (1984) utilized to check out work values and commitment ended up being calculated by questions like "if a similar task had been recommended yet another destination, could you keep to you need to take the offer?" and price from 1 (excellent level) to 6 (almost no level). The end result proposes that commitment is highly relevant to with intellectual work value variables compared to people which are instrumental. There was a correlation between use and dedication of abilities, task interest, freedom and accomplishment. The research additionally identified that there surely is additionally a correlation with pay and which was classified as an ongoing work value item that is instrumental.

\section{Job Satisfaction}

Bart Cambre (2015) et al attempted to analyze the task that is working knowledge of among group level. Further, researcher additionally attempted to browse the shared variance in task satisfaction at different examples of jobs into the business in particular sector that is commercial. It had been found that there happen significant and team that is dependable in work satisfaction within banking sector. It had been learnt that decision authority is more important for work satisfaction than other facets. It had been further inferred that to focus more on structural differences and alternatives which are organizational may influence task design and work system. In 2015 an extensive research had been carried out by Titus Oshagbemi (2015) to investigate and compare the task satisfaction among academicians and their supervisors. He tested whether academicians with administrative power or academicians without administrative energy are far more pleased. After the scholarly study it positively had been found that teachers in university are pleased fairly within their task. Further it absolutely was also inferred that there are significant differences between academicians and their managers on such basis as satisfaction level. Further he may be describing any power that is administrative by seniority in age, solution seniority and rank will influence task satisfaction favorably amount of academicians. Susan J. Linz (2015) investigates whether Russian workers are pleased of their work or elsewhere not. And likewise examined the nice grounds for dissatisfaction along with precisely what treatments may be taken as corrective measures. He carried out a scholarly study among 1200 people regarding their work satisfaction. He investigated on both worker traits (objective traits) and faculties which are subjective. Objective faculties ought to include sex, age, training, work experience, unemployment experience, supervisory duties, marital status, wide range of jobs held during the time of the meeting, new improvement in workplace etc. in addition to the subjective faculties includes the mind-set towards the job. And also ascertained the correlation of task satisfaction with organizational dedication. He's describing that the reward framework and better management training will favorably influence the teamwork effectiveness, and it will reduce steadily the return and certainly will increase the task satisfaction. Further he had been remarked that job satisfaction and work efficiency have actually good correlation and work return will adversely correlated with task satisfaction in our midst workers both will lead to performance that is firm. In the problem of Russian workers they are going to offer importance to increasing performance that is firm minimum expense. Sharanjit Uppal (2015) had one presumption that the workers with disabilities will be less satisfied soon inside their jobs than the workers without any disabilities. And he conducted a survey on that basis on such form of employees. The journalist is telling studies which is previous perhaps not mention the facets which are impacting by these workers that will induce dissatisfaction. He introduced some workplace faculties towards the model and describing that the working task satisfaction will increase with one of these traits being brand new those employees having any flexibility impairment no further is going to be dissatisfied with their work while the employees without disabilities. He might be figured the reason why behind the task satisfaction room between employees with impairment and without disability would be the help that is technical supervisor accommodation. The satisfaction level will increase in the event that management provides better technical help with such forms of employees.

\section{Employment engagement}

Employees are an advantage for an organization. Using the organization's scholarly capital has turned into a wellspring that is important of hand. (Artur, 1994; Becker and Huslid, 2000; Buckingham and Vosburgh; 2001) a way that is good can efficiently explore these issues and revenue by their funds that is scholarly is encourage Employee Engagement. Associated with representatives are invigorated and energetic regarding the work that is ongoing are doing. With passion comes fervor, effectiveness and eagerness. (Kroth and Boverie, 2003) it is all that much a company's self-pastime that will construct riches as quick as displeased one can demolish it(Catlette and Hadden, 2001). (Wildermuth and Pauken 2008) centers around the facets being major impact the worker engagement particularly ecological and employee commitmentfactors along with that, the scientists tried to change engagement equation by including task and person. They reached in closing that caused by employee commitment plus the ecological facets in worker engagement and mention that in a climateal friendly social scenario help to keep respectful relationship among employees and inspire the employees to trace typically the most popular and stirring vision that is future. Musgrove et.al 2014, used a survey method by collecting the reaction of 502 solution workers owned by service that is a couple of. The analysis identifies the motivators of worker engagement and also the solution that is beneficial in company. The choosing shows that the revenue improvement and price containment methods differentially influence the worker engagement and so the ongoing service climate inside the business. Saks 2006 tries to investigate the together that is last future aftereffects of business and work

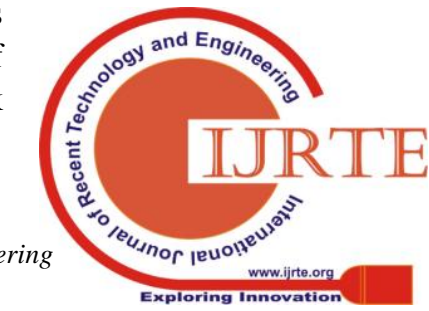


engagements into the context of social trade concept. Survey technique ended up being followed and responses from 102 employees were gathered. Among the respondents $60 \%$ had been females and age that is average of were 34 . Individuals had a work that is average of 12 years and serving the organization that is same the common amount of 5 years plus in equivalent work for 4 years. The research points out that working organization and job engagement aren't one and very same. The job engagement is directed by work characteristic whereas company engagement may be the outcome that is total of justice. In the other side, alleged support that is organizational both work and organizational engagement mediated the relationships in the middle of your antecedents and task satisfaction, organizational dedication, motives to quit, and citizenship behavior that is organizational. Ferreira and oliveira 2014 tries to establish a relationship between business duties that is worker engagement that is social. Survey method was indeed utilized and reactions from individuals owned by fundamental, interior and CSR that is outside had been collected. The study reveals that the internal and CSR that is external doesn't have any effect that is considerable the task engagement of workers. Nonetheless, people who find themselves at the mercy of only CSR that is external less involved compared to those who're at the mercy of CSR that is inside. Bhatnagar 2007 the research tries to examine the skill management and worker engagement to the help to its association of various research design. The researcher utilized a two stage research, had been in extremely very first stage ended up used to assemble information by interviewing 272 BPO/ITES workers by means of gallupgullup or q12 workplace review. The phase that is second ended up being taken to gather examples in one BPO organization which has been into the first phase at a random foundation plus the analysis of the collected data was done making use of tools such as element analysis and analysis that is content. The results of the study that is scholarly experienced convergence because of the expectation. The analysis describes that the component that is lower in the initial period and which shows low work engagement for a time amount of 16 months and the high element loading in to the intermediate or moderate period shows a high engagement degree, whilst the data replicate because of high commitment but simply for a brief period of the time. Organizational tradition, career planning along with incentives and assistance that is organizational the 3 different factors which as contained in the second stage loading, whenever very first two were indicative of high attrition. Shuck, Rocco, Alboronoz 2011 extended the study by adopting situation that is method that is yin's and gathered supportive proof from international corporations utilizing semi- organized interviews and findings. The researcher merged the duty of Khan and Maslow for just about any framework that is conceptual. To express the text between your engagement efforts and experience, post information analysis and collection that is content utilized as methodology. Relationship accessory and development to coemployees, office climate and opportunities for learning are the three aspects developed in the post analysis. The analysis also discovered supportive proof for any significance of maintaining good relationship at your workplace as the development of a simple yet effective organizational tradition for better climate that is working.

\section{Objectives}

The major objective of the study is to find the relationship of employee commitment and job satisfaction with the employee engagement.

\section{RESEARCH METHODOLOGY}

\section{Pilot Study}

A pilot study was conducted for a sample size of two hundred respondents and they were drawn from 5 IT sector of South India. The validity and the reliability of the scales were tested. The pilot study was done with no issues and some of the questions were eliminated after pre-testing.

\section{Population and Sample}

All units pertaining to a study is called a population and the sample is the subset of a population. According, to NASSCOM report, the top 5 companies were listed and from this companies the samples were chosen.

- Table 1 Number of Employees from the Companies

\begin{tabular}{|c|c|c|}
\hline S.No & Company & Employees \\
\hline 1 & Company 1 & 305431 \\
\hline 2 & Company 2 & 160,405 \\
\hline 3 & Company 3 & 154,297 \\
\hline 4 & Company 4 & 95,522 \\
\hline 5 & Company 5 & 95,300 \\
\hline $\begin{array}{c}|c| \\
\text { TOTAL } \\
\text { EMPLOYEES }\end{array}$ & \multicolumn{2}{|c}{} \\
\hline
\end{tabular}

\section{Sample Size Calculation}

The sample size for the population is calculated by the following formula.

$$
\begin{aligned}
& \text { Sample Size }= \text { Old SS } \\
& \text { (ss-1) } \\
& 1+----------
\end{aligned}
$$

pop

Where,

$$
\mathrm{SS}=\frac{\mathrm{Z}^{2} *(\mathrm{p}) *(1-\mathrm{p})}{\mathrm{c}^{2}}
$$

And the sample size is found to be 599.56 which is approximately 600 .

\section{Measuring Instruments \\ Employee Engagement}

Employee engagement scale was adopted from Wilmar B. Schaufeli and Arnold B. Bakker (2006). The scale has three dimensions one is Vigor the second is Dedication and third dimension is Absorption with five point scale where 1 is Strongly Disagree and 5 is Strongly Agree.

\section{Job Satisfaction}

Job Satisfaction scale used 14 item questionnaire which is specified by Hatfield (1985) and it includes Personal growth satisfaction, Job Security \& Compensation, Co-worker Satisfaction \& supervisory Satisfaction.

Employee Commitment

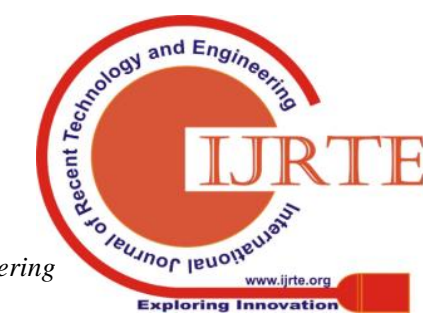


Employee commitment scale was adopted from Allen \& Meyer (1990) where they proposed a three component model in their study and the component proposed are such as Affective Commitment, Continuance Commitment and Normative Commitment which explains the emotional belongingness to their organization, the cost associated with living in the organization and the feeling of compulsion to remain with the organization respectively.

The data collection was done through questionnaire method. The respondents chosen where the IT employees from select 5 companies. The questionnaire has been given to the employees through e-mail and in person. Total number of data used for the study is 785 .

\section{Normality}

Normality is used to test whether the data distributed is normal. For the test to be normal it has to get skewness and kurtosis, where the values should range from +2 to -2 and the values are achieved in the study and so the data distribution is normal.

\begin{tabular}{|l|l|l|}
\hline Study variables & Skewness & Kurtosis \\
\hline $\begin{array}{l}\text { Employee } \\
\text { Commitment }\end{array}$ & .532 & -.215 \\
\hline Job satisfaction & .059 & -.541 \\
\hline $\begin{array}{l}\text { Employee } \\
\text { Engagement }\end{array}$ & 1.603 & 1.564 \\
\hline
\end{tabular}

\section{Reliability}

Cronbach Alpha was done too check the reliability of the data and it is found to be similar with the literature.

The scales for measuring the three constructs, Job satisfaction, Employee Commitment and Employee Engagement were drawn from the study. Cronbach's Alpha co efficient for all the variables are greater than 0.7 and so we conclude the data is reliable.

\begin{tabular}{|l|l|}
\hline Study variables & Cronbachs Alpha \\
\hline Employee & \\
Commitment & 0.975 \\
\hline Job satisfaction & 0.945 \\
\hline $\begin{array}{l}\text { Employee } \\
\text { Engagement }\end{array}$ & 0.975 \\
\hline
\end{tabular}

\section{Tools and software used}

The data collected is analysed with the statistical tools using SPSS20, Correlation and Regression is used to find the relationship between the variables

\section{Data analysis}

The objective of the study is to project the relationship of companies considered with respect to Employee Engagement.

The present study has 785 samples covering 5 companies namely Company $1\left(\mathrm{n}_{1}=153,19.49 \%\right)$, Company $2\left(\mathrm{n}_{2}=188\right.$, $23.95 \%)$, Company $3\left(\mathrm{n}_{3}=122,15.54 \%\right)$, Company $4\left(\mathrm{n}_{4}=\right.$ $165,21.02 \%)$ and Company5 $\left(\mathrm{n}_{5}=157,20.0\right)$. To observe the relation between the variables considered and to validate whether these variables are significant enough to explain about the employee engagement in each company, the so called statistical tools, Correlation and Regression analysis are considered.

\section{Correlation}

Correlation is being done to find the relationship between the study variable and the hypothesis are as follows

\section{Data Collection}

H1: There is a significant relationship between employee commitment and job satisfaction.

$\mathrm{H} 2$ : There is a significant relationship between employee commitment and employee engagement.

H3: There is a significant relationship between job satisfaction and employee engagement.

\section{Multiple Regression Model}

After checking out the positive and strong relationship of job satisfaction and employee commitment on employee engagement a multiple regression analysis has been done to check the impact of job satisfaction and employee commitment on employee engagement.

Employee engagement predicated by Job satisfaction and Employee commitment

\begin{tabular}{|r|l|}
\hline H4 & $\begin{array}{l}\text { There is a significant relationship } \\
\text { between job satisfaction and employee } \\
\text { engagement. }\end{array}$ \\
\hline H5 & $\begin{array}{l}\text { There is a significant relationship } \\
\text { between employee commitment and } \\
\text { employee engagement. }\end{array}$ \\
\hline
\end{tabular}

\begin{tabular}{|c|c|c|}
\hline Variables & $\begin{array}{c}\text { Pearson Co } \\
\text { efficient }\end{array}$ & Significance \\
\hline $\begin{array}{c}\text { Employee Commitment } \\
\text {---> Job Satisfaction }\end{array}$ & 0.979 & 0.000 \\
\hline $\begin{array}{c}\text { Employee Commitment } \\
\text {--- Employee Engagement }\end{array}$ & 0.747 & 0.000 \\
\hline $\begin{array}{c}\text { Job Satisfaction ---> } \\
\text { Employee Engagement }\end{array}$ & 0.712 & 0.000 \\
\hline
\end{tabular}

\section{Model Summary}

\begin{tabular}{|l|l|l|l|l|}
\hline Model & R & R Square & $\begin{array}{l}\text { Adjusted R } \\
\text { Square }\end{array}$ & $\begin{array}{l}\text { Std. Error of } \\
\text { the Estimate }\end{array}$ \\
\hline 1 & $.814^{\mathrm{a}}$ & .657 & .637 & .4169 \\
\hline
\end{tabular}

Published By: 


\section{Interpretations}

$\mathrm{R}$ is the correlation, its value is 0.814 and $\mathrm{R}$ square is the degree of determination, its value is 0.637 . The degree of determination shows the extent to which job satisfaction and employee commitment influence employee engagement. Here the employee engagement is determined to an extent of $65 \%$ by job satisfaction and employee commitment.

\section{Anova Table:}

\begin{tabular}{|c|c|c|c|c|c|c|}
\hline \\
\hline & Nowet & Squares & 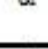 & Squere & 1 & 5 . \\
\hline \multirow{3}{*}{1} & Regression & 279.047 & 2 & \multirow{3}{*}{$\begin{array}{c}139.023 \\
201\end{array}$} & \multirow[t]{3}{*}{191.4975} & \multirow[t]{3}{*}{$.000^{2}$} \\
\hline & Residual & 113.942 & 516 & & & \\
\hline & Total & 392.989 & 522 & & & \\
\hline
\end{tabular}

a. Dependent Vrriable: Employee engagement

b. Predictors: (Constant), Employee commitment and Job satisfaction

ANOVA table shows that the significant value is less than 0.01 , which means the dependent variable that is employee engagement is significantly predicted by the independent variables namely job satisfaction and employee commitment at $99 \%$ confidence level

\begin{tabular}{|c|c|c|c|c|c|c|}
\hline \\
\hline \multirow{2}{*}{\multicolumn{2}{|c|}{ Made1 }} & \multicolumn{2}{|c|}{$\begin{array}{l}\text { Unstandardizad } \\
\text { Coefficients }\end{array}$} & $\begin{array}{l}\text { Standardized } \\
\text { Coefficients }\end{array}$ & \multirow[t]{2}{*}{ t } & \multirow[t]{2}{*}{ Sig. } \\
\hline & & B & Std. Error & Beta & & \\
\hline \multirow{3}{*}{1} & (Constant) & .748 & .127 & & 5.887 & .037 \\
\hline & Job satisfaction & .341 & .045 & .069 & 7.577 & .047 \\
\hline & Employee commiment & .846 & .046 & 397 & 18.391 & .000 \\
\hline
\end{tabular}

Work Performance $=0.748+0.341$ (job satisfaction) +0.846 (employee commitment)

Among the above two factors employee commitment have a significant and highest impact on the employee engagement. Job satisfaction is significantly contributing to the employee engagement. Hypothesis [H4] is accepted and shows that is a significant relationship between job satisfaction and employee engagement. Hypothesis [H5] is accepted and shows that there is a significant relationship between employee commitment and employee engagement.

\section{DISCUSSION AND CONCLUSION}

The study suggest the companies to concentrate on all the variables equally in the organization as the analysis shows a good amount of relationship between the variables used in the study and all the variables plays a major role in contributing for employee engagement. Job satisfaction is imperative for engaging the employees. In the absence of satisfaction among employees what so ever the motivational strategies are applied, it won't facilitate in retaining the employees. Any employee joins an organization keeping in mind a conducive working environment. Employees with skills and potentials looks for better working condition and support from the management this will lead to employee commitment. Employees with potentials always aspire to grow along with the organization. Hence, employee commitment plays a vital role in engaging the employees. On the other hand if the employee commitment is low in nature employees will be having the feeling of belongingness towards the organization.

The theoretical framework proposes the relationship between employee engagement, job satisfaction and employee commitment. The two variables are highly significant with employee engagement and are good in engaging employees. The study has found that job satisfaction is correlated with employee engagement and serves as the main variable in engaging employees. With job satisfaction and employee commitment and employee engagement as variables the study has helped in developing a holistic model. This helps the other companies an easy approach to engage their employees by developing organizational strategies.

If Job Satisfaction does not exist in an employee, his level of engagement would be minimal. Employee may be working to maintain hygiene factors according to Herzberg but the management won't be able to motivate him to either enhance productivity or engage him with the organization.

Commitment comes when the hygiene factors are maintained. Every employees looks forward to ensure that the employee is committed. Only then they can motivate them to be engaged. Hence, it observed that all the four variable are equally mandatory for employee engagement.

\section{Limitations}

- The cross sectional design may hamper the applicability of causal conclusions drawn from the findings.

- The study used the self-rater to measure all the constructs.

- This study pertains to Chennai and Bangalore only and it may differ in other parts of the World.

- Five companies has been taken and some more companies can also be included.

\section{Future Research}

Future researcher can include more variables and can also use more tools and the data can be collected through different methods and the samples can also be increased. The data can be collected from different levels of employees like top management, middle management and can also be increased with organizational engagement, team engagement and job engagement.

\section{REFERENCES}

1. Arthur, J. (1994). Effects of human resource systems on manufacturing performance and turnover, Academy of Management Journal, 37 (3), pp. 670-687.

2. Bates S (2004), 'Getting engaged', HR Magazine, 49(2), 44-51

3. Buckingham M \& Vosburgh R (2001). "The 21stCentury Human Resources Function: It's the Talent, Stupid!" Human Resource Planning, 24(4), pp. 17-23.

4. B. Catlette, R. Hadden, Contented cows give better milk: the plain truth about employee relations and your bottom line, Germantown: Saltillo Publishing.

5. Cristina de Mello e Souza Wildermuth, Patrick David Pauken, (2008), A perfect match: decoding employee engagement - Part I: Engaging cultures and leaders, Industrial and Commercial Training, Vol. 40, Issue: 3 , pp.122-128,

https://doi.org/10.1108/00197850810868603

6. Dov Elizur (1996), Work values and commitment, International Journal of Manpower, Vol. 17, Issue: 3, pp.25-30, https://doi.org/10.1108/01437729610119496

7. Huselid, M. A. (1995), The impact of human resource management practices on turnover, productivity, and corporate financial performance, Academy of Management Journal, 38, 635-672.

8. Jyotsna Bhatnagar, (2007), Talent management strategy of employee engagement in Indian ITES employees: key to retention, Employee Relations, Vol. 29, Issue: pp.640-663, https://doi.org/10.1108/01425450710826122

9. Kahn WA (1990), Psychological conditions of personal engagement and disengagement at work, Academy of Management Journal, 33(4), 692-724.

10. Langelaan $\mathrm{S}$, Bakker $\mathrm{AB}$, van Doornen LJP, Schaufeli WB 
(2006), Burnout and work engagement: do individual differences make a difference?, Personality and Individual Differences, 40, 521-532.

11. M. Brad Shuck, Tonette S. Rocco, Carlos A. Albornoz, (2011), Exploring employee engagement from the employee perspective: implications for HRD, Journal of European Industrial Training, Vol. 35 Issue: pp.300-325, https://doi.org/10.1108/03090591111128306.

12. Pedro Ferreira, Elizabeth Real de Oliveira (2014), Does corporate social responsibility impact on employee engagement?, Journal of Workplace Learning, Vol. 26 Issue: 3/4, pp. 232-247, https://doi.org/10.1108/JWL-09-2013-0070

13. Titus Oshagbemi, (2003), Personal correlates of job satisfaction: empirical evidence from UK universities, International Journal of Social Economics, Vol. 30, Issue: 12, pp.1210-1232, https://doi.org/10.1108/03068290310500634

14. Richman, A. (2006), "Everyone wants an engaged workforce how can you create it?", Workspan, Vol. 49, pp. 36-9.

15. Robinson, J. (2004), A world of cities. The British Journal of Sociology, 55, pp. 569-578. doi:10.1111/j.1468-4446.2004.00038.

16. Saks AM (2006), Antecedents and consequences of employee engagement, Journal of Managerial Psychology, 21(7), pp. 600-619.

17. Semykina, A. and Linz, S. J. (2013), Job Satisfaction and Perceived Promotion Equality, Kyklos, 66, pp. 591-619. doi:10.1111/kykl.12038

18. Uppal, Sharanjit. (2015), Employment patterns of families with children, Insights on Canadian Society, Statistics Canada Catalogue no. 75-006. 